
DOI : $10.14746 /$ ps.2020.1.29

\section{Iran, Terrorism, and ISIS. Radosław Fiedler's Interview with Bruce Hoffman ${ }^{1}$}

Bruce Hoffman is a political analyst specializing in the study of terrorism and counterterrorism, insurgency and counterinsurgency. He is a tenured professor at Georgetown University's Edmund A. Walsh School of Foreign Service, where between 2010 and 2017 he was the director of the Center for Security Studies and director of the security studies program. Hoffman is the second-longest-serving director in the centre and program's threedecade history.

Radoslaw Fiedler: In 1984 Iran was enlisted by the State Department as a state sponsor of terrorism but it did not prevent Iranian influence through its proxies in Iraq, Lebanon, Yemen, and is supporting Bashar al Assad in Syria. Through years Iran built stronghold and is developing networks across the region. To that challenge, the US has responded through sanctions and by a drone strike and assassinating Al-Quds commander Qassam Suleimani. How should be evaluated the US counterterrorism policy to Iran? Is Washington's response to Teheran adequately and effective?

Bruce Hoffman: The killing of Qassam Solemani underscored his role in organizing terrorist plots against US forces in Iraq and in shoring up Iran's dominance over that country. He organized and coordinated terrorist networks and through the Al-Quds Force, an external arm of the Iranian Revolutionary Guards, consolidated Iran's influence in Iraq. However, he was an Iranian flag officer in that country's military and official representative of the Islamic Republic and tare long-established international law provisions against the assassination of serving military officers. It was thus a significant blow to Iran but also a debatable move in terms of international law. It may be that President Trump's deliberate unpredictability, as the assassination is meant to convey, is meant to scare Iran and thus constrain its terrorist and asymmetric activity against the US and its allies. For decades the US responded improperly to Iranian hostile acts. The hostage crisis in years 1979-81 undermined US credibility through its inability to mount an appropriate response to serial instances of Iranian-backed terrorist acts and provocation. That paralysis may have emboldened Iran to spread its malignant activity to Europe and also Argentina. One positive effect - the aftermath of the hostage crisis and failed rescue mission in 1980 was that it resulted in the creation of the US military joint Special Operations Command and serious attention thereafter was paid to building up a robust American special operations capability. I published a report for the RAND Corporationin1991 entitled, Recent Trends and Future Prospects of Iranian-sponsored International Terrorism. It described Iran's policy of sponsoring terrorism as an instrument of its foreign policy - to be used when Iran wanted to and then put aside for some future time when it might again prove useful. That analysis from nearly thirty years ago remains completely relevant. Because of Iran's inherent conventional military weakness, it means that's country's clerical elite can rely on this

${ }^{1}$ Interview was conducted during the research within the Bekker Program (NAWA) at Columbia University in New York City, February 5th, 2020. 
clandestine instrument of force projection. There is always that capability at their disposal which for Iran immensely useful in eliminating dissents or deterring threats from rival or enemy powers.

Iran and Shia militias and Hezbollah on the one hand - the other has been complicated relations between Iran and Al-Qaeda. Why Iran was a safe haven and harbour for AlQaeda? Which motivations were behind it?

Teheran did not want al-Qaeda attacking Iranian territory. That is the simple explanation. It more complicated though because from one side they help to fight Al Qaeda in Syria, while concurrently providing senior Al Qaeda leaders sanctuary in Iran. The safe havens in Pakistan and Iran were central to Al-Qaeda's survival. Motivations: The enemy of my enemy is my friend type mentality. Cathy Scott-Clark and Adrian Levy make this clear in their excellent book, The Exile: The Stunning Inside Story of Osama Bin Laden and Al Qaeda in Flight, Bloomsbury (2017). The most evident examples were Saif al-Adl and Abdullah Ahmed Abdullah - high-ranking members of al-Qaeda who are reportedly hiding in Iran.

Why did the ISIS spread so rapidly across Iraq and Syria? Is it possible resurgent of the caliphate?

There were many causes for the rampant growth of Salafists and a combination of misperceptions and underestimation of the threat from ISIS mean that they initially did not face any significant resistance. The successful capture of Mosul also was caused by eroding the morale of Iraqi security forces - around 30K of them fled. Noteworthy, the ISIS's strength was a combination of successful religious favour, appeal to jihadism and expertise from former Saddamists. That was a key answer to its ruthlessness and efficiency. Additionally, the enthusiasm of younger people who were provided a new platform for recruitment with attractive propaganda through social media. This threat will not fade away. Now Iraqis highly stressed economically and politically, torn with divergent interests and sectarian divisions with Iranian rising influence in these circumstances ISIS's remnants will thus continue terrorist activity in Iraq.

Almost twenty years ago was 9/11 - how since that time has changed terrorism? In 2011 and 2019 - leaders of Al Qaeda and ISIS were eliminated. Is the targeted killing an effective response to undermine terrorism?

Since 2001 terrorism has changed a lot. Now we are facing many more networks, cells, and existing different groups. Al-Qaeda, ISIS, Iranian proxy groups - terrorism has spread across many regions and resulted in the emergence of the highly consequential and challenging lone wolf phenomenon. Terrorism poses an even greater threat today Sterrorists are using different channels and social media, communicators for orchestrating their activity. The lone wolf is difficult to trace since the perpetrators are acting without structures and networks.

Targeted killing is a useful tactic but only a tactic that is part of a broader counterterrorism strategy. In the case of Baghdadi and bin Ladin, they were brought to justice and their 
deaths destroyed the sense of invincibility claimed respectively by ISIS and al Qaeda. But we need to be more realistic about our counterterrorism accomplishments - in that, leader elimination did not abolish or even seriously diminish or undermine these groups' activity. In some cases, a new commander might be worse than his predecessor.

Radosław FIEDLER New York 